\title{
Leaf-litter decomposition and nutrient dynamics of five selected tropical tree species
}

\author{
S. Bhattarai ${ }^{1 *}$ and B. Bhatta ${ }^{1}$
}

\begin{abstract}
Leaf-litter decomposition in terrestrial ecosystems has a major role in recycling the nutrients to the soil. Nutrient dynamics is the way nutrients cycle in an ecosystem. The present study was conducted for five selected tropical tree species viz. Shorea robusta, Ficus hookeri, Mallotus philippensis, Artocarpus lakoocha and Dillenia pentagyna at Hetauda, Makawanpur. This paper aims to determine the litter decomposition rateconstant and nutrient mineralization pattern of the selected species. The litter-bag method was used to assess the decomposition and nutrient dynamics for one year. Both decomposition rate-constant and weight loss were highest for $M$. philippensis (\% weight loss $=73.49 ; \mathrm{k}=0.33$ ) and lowest for S. robusta $(\%$ weight loss $=54.01 ; \mathrm{k}=$ $0.18)$. In general, weight remaining showed a strong negative correlation with $\mathrm{N}$ and $\mathrm{P}$ concentration but a slightly negative with $\mathrm{K}$. However, the remaining weight of litter showed a strong positive correlation with $\mathrm{C}: \mathrm{N}$ ratio, thus indicating a good predictor of mass loss and mineralization. The study showed that there was no net release of nitrogen during the one-year study period; however, the net $P$ release was found to be highest for $S$. robusta followed by $D$. pentagyna and the net $\mathrm{K}$ release was highest in F. hookeri followed by $A$. lakoocha.
\end{abstract}

Keywords: Immobilization, leaf-litter decomposition, nutrient dynamics, weight remaining

$\mathrm{T}$ The dead plant materials such as leaves, bark, needles, and twigs that have fallen on the ground are called litter. As the majority of organic matter $(\mathrm{OM})$ produced by plants is returned to the soil as litter, the transfer of nutrients and energy from living biological components to the soil is the important mechanism of nutrient recycling. In the cycling of such nutrients, decomposition processes have a crucial role by releasing a complex organic compounds into the simple usable form for proper growth and development of plants (Saha et al., 2016). Litter has thus occupied the attention of ecologists as it is an important factor in ecosystem dynamics to determine ecological productivity and may be useful in predicting soil fertility (Guendehou et al., 2014).

The process of biological disintegration of dead organic materials whereby mineralization of complex organic compounds into simple inorganic forms takes place is called decomposition (Saha et al., 2016). The process of decomposition is primarily carried out by bacteria and fungi, thus the rate of decomposition entirely depends on microbial activities which in turn, get affected by soil character and climatic condition in an area (Berg and McClaugherty, 2014). Moreover, Gautam and Mandal (2016) have also reported the effect of disturbance on litter dynamics in a moist tropical forest. Litter mass loss or decay is the sum of carbon dioxide release and discharge of compounds that contains both carbon compounds and nutrients (Brady and Weil, 2010). In general, three major factors viz. site environmental condition (particularly climate), litter quality and soil biota play a crucial role on decomposition of Leaf-litter; however, climate is known to be the dominant factor followed by litter quality influencing the decomposition process (Austin

1. Agriculture and Forestry University, Faculty of Forestry, Hetauda, Nepal.*Email: sbhattarai@afu.edu.np 
and Vitousek, 2000; Berg and McClaugherty, 2014).

Nutrient dynamics is broadly defined as the way nutrients are taken up, retained, transferred, and cycled over time and distance, in an ecosystem (Hauer and Lamberti, 2006; Allan and Castillo, 2007). Decomposition process plays an important role in maintaining soil fertility in terms of nutrient cycling and formation of soil OM (Usman et al., 2000; Singh et al., 2007; Guendehou et al., 2014). Slow decomposition rates result in the building up of $\mathrm{OM}$ and nutrient stocks in soil; however, fast decomposition rates help to meet plant intake requirements (Isaac and Nair, 2005). Litter diversity also influences the activity of soil communities and processes during decomposition (Chapman and Koch, 2007). Moreover, some chemical characteristics of the litter materials like lignin, polyphenol, cellulose, and hemicellulose along with $\mathrm{C}: \mathrm{N}$ ratio affect decomposition (Silveira et al., 2011). A litter with higher initial $\mathrm{N}$ concentration usually shows a higher mass loss; however, the importance of initial $\mathrm{N}$ concentration decreased with time (Ross et al., 2002).

In the traditional mountain farming system of Nepal, there exists a triangular relationship among forest, agriculture, and livestock. In this system, forest trees are responsible to provide nutrient to the soil surface in the form of leaflitter in both forest and agricultural lands. As a result, the tradition of harvesting leaf-litters from the forests for agricultural use has been a complementary practice of agriculture in rural Nepal. Leaf-litters have been used for livestock bedding and farmyard manure (FYM) production. Thus, decomposed leaf-litters become a major source of plant nutrients to the agricultural field as manure. However, most of the farmers do not know the chemical nature of the leaf-litters and their decomposition mechanism as some of the species are with complex structural biomolecules that do not provide nutrients easily. Therefore, the present study was carried out to compare the leaf-litter decomposition and nutrient dynamics of frequently used species in the study area.

\section{Materials and methods Study area}

The study was carried out in tropical lowland (about $450 \mathrm{~m}$ altitude) of Makawanpur district, central Nepal. Shorea robusta, Terminalia chebula, T. bellirica, Mallotus philippensis, Ficus spp., Adina cordifolia, Acacia catechu and Dalbergia sissoo were the common species found in the study area. The experiment was set up in tropical climatic conditions having the average temperature of $29.18^{\circ} \mathrm{C}$ and $173.64 \mathrm{~mm}$ rainfall during the study period. The temperature and rainfall variations in the study area are shown in Figure 1.

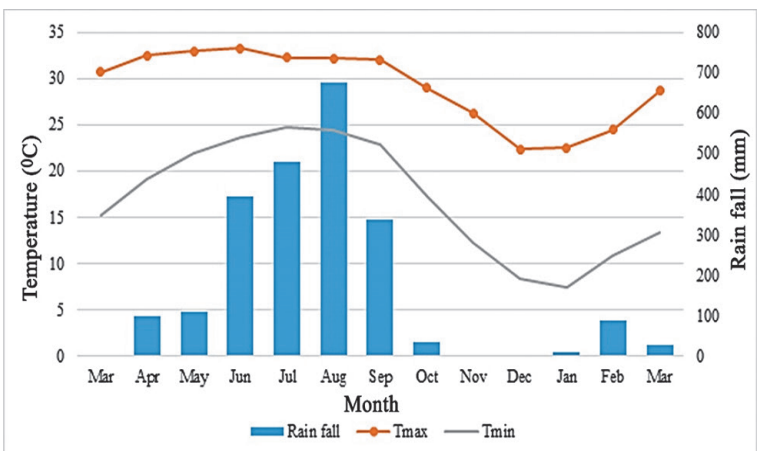

Figure 1: Monthly variation of rainfall, temperature (maximum and minimum) of the study area

Source: Department of Hydrology and Meteorology, 2019

\section{Selection of species}

A total of five tree species viz. S. robusta, $F$. hookeri, M. philippensis, A. lakoocha and D. pentagyna were selected for the study based on the key informant interview with the local farmers focusing on their use-values. Of them, $S$. robusta, $M$. philippensis and D. pentagyna were found to be highly used for animal bedding and composting whereas $F$. hookeri and A. lakoocha were used for fodder and composting.

\section{Methods}

The decomposition of the Leaf-litter of the selected tree species was studied in the open land using a nylon bag technique following Gilbert and Bocock (1960). The newly fallen leaves of the selected five species were collected from the forest-floor during the peak litter fall period (March). The litter samples were identified based on the morphological characters, and oven-dried at $70^{\circ} \mathrm{C}$ to a constant weight in the laboratory. For each species, 36 litter bags were prepared enclosing a $50 \mathrm{~g}$ sample of the oven-dried leaves 
into a $25 \times 25 \mathrm{~cm}$ sized $2 \mathrm{~mm}$ thick nylon mesh which was small enough to prevent the major losses of the litter sample yet large enough to permit microbial activity, and placed at the open area during March, 2018. The litter-bags were placed separately in an open field in such manner that they were in contact with soil, and care was taken not to disturb the floor vegetation. Three litter bags of each species were recovered randomly at monthly interval from March, 2018 to March, 2019. Afterward, the samples were made free from dust and other unnecessary materials, and oven-dried at $70^{\circ} \mathrm{C}$ and weighted. Then, the samples were immediately brought to the Soil Laboratory at Hetauda for nutrient analysis. The nitrogen $(\mathrm{N})$ content was estimated using the Micro-Kjeldahl Method whereas the phosphorus (P) and potassium (K) were determined by adopting the Spectrophotometry Method and Flame Photometer Method, respectively as per Jackson (1967). The climatic data (temperature and rainfall) obtained from the Department of Hydrology and Meteorology were used.

\section{Data analysis}

The decomposition rate-constant was calculated using the exponential decay model of Olsen (1963) which is expressed as $-\mathrm{X} / \mathrm{X}_{\mathrm{o}}=\mathrm{e}^{-\mathrm{kt}}$,

where, $\mathrm{X}$ is the dry weight remaining at time $\mathrm{t}$ (year), $\mathrm{X}_{\mathrm{o}}$ is the original dry weight of the litter, and $\mathrm{k}$ is the decay rate coefficient.

The time required for half-life $\left(\mathrm{t}_{50}\right)$ was calculated as $-\mathrm{t}_{50}=0.693 / \mathrm{k}$
Likewise, correlation analysis was used to examine the relationship of the remaining weight with the remaining $\mathrm{OM}, \mathrm{N}, \mathrm{P}$ and $\mathrm{K}$.

\section{Results and discussion Initial chemical composition}

The initial nutrient composition of Leaf-litter showed variation among the selected tree species (Table 1). The highest nitrogen concentration was estimated in A. lakoocha $(0.07 \%)$ followed by $F$. hookeri and $M$. philippensis $(0.062 \%)$ and so on. The maximum phosphorus was in $D$. pentagyna $(0.145 \%)$ followed by $F$. hookeri $(0.131 \%)$. and least in M. philippensis $(0.078 \%)$. Similarly, potassium was highest in F. hookeri $(21.159 \%)$ followed by S. robusta (5.62\%).

\section{Weight loss pattern}

At the end of the study, the maximum weight loss (73.49\%) was observed in M. philippensis whereas this value was minimum (54.01\%) in $S$. robusta. Likewise, the annual decomposition constant $(\mathrm{k})$ values for the different species ranged from 0.18 (S. robusta) to 0.33 (M. philippensis) and the halflives $\left(\mathrm{t}_{50}\right)$ from 3.85 to 2.1 , respectively (see Table 2). Comparatively, the rates of decomposition of the leaf-litters of F. hookeri, M. philippensis, A. lakoocha and D. pentagyna were found to be higher at the end of the first month followed by a gradual mass loss for the subsequent days. However, the rate of decomposition of S. robusta was not higher during the first months as found in the other species; rather the rate was higher at the end of the second month (Figure 2).

Table 1: Initial chemical composition and decomposition constant of Leaf-litter

\begin{tabular}{|l|l|l|l|l|l|l|}
\hline Species & Local name & OM & N & P & K & C:N \\
\hline $\begin{array}{l}\text { Shorea robusta } \text { Gaertn. } \\
\text { Ficus hookeri Miq. }\end{array}$ & Sal & 6.19 & 0.042 & 0.116 & 5.620 & 147.376 \\
\hline $\begin{array}{l}\text { Mallotus philippensis (Lam.) } \\
\text { Mull. Arg. }\end{array}$ & Sindure & 7.28 & 0.062 & 0.131 & 21.159 & 118.0654 \\
$\begin{array}{l}\text { Artocarpus lakoocha } \text { Wall. } \\
\text { ex Roxb. }\end{array}$ & Badahar & 6.32 & 0.062 & 0.071 & 2.382 & 106.189 \\
\hline $\begin{array}{l}\text { Dillenia pentagyna } \text { Roxb. } \\
\text { Tatari }\end{array}$ & 6.86 & 0.048 & 0.145 & 2.429 & 143.9757 \\
\hline
\end{tabular}

(Note: OM - Organic matter; N - Nitrogen, P- Phosphorus, K- Potassium, C - Carbon, k - Decomposition rate-constant) 
Table 2: Annual weight loss, decomposition constant $(k)$, half-life $\left(t_{50}\right)$ and $C: N$ ratio

\begin{tabular}{|c|c|c|c|c|c|c|}
\hline \multirow{2}{*}{$\begin{array}{l}\text { S. } \\
\text { N. }\end{array}$} & \multirow[b]{2}{*}{ Species } & \multicolumn{3}{|c|}{ Dry mass } & \multirow{2}{*}{$\begin{array}{l}\text { Initial } \\
C: N\end{array}$} & \multirow[b]{2}{*}{ Final $\mathbf{C}: \mathbf{N}$} \\
\hline & & $\mathbf{k}$ & $\begin{array}{l}\text { Weight loss } \\
(\%)\end{array}$ & $\mathbf{t}_{\mathbf{5 0}}$ & & \\
\hline 1. & S. robusta Gaertn. & 0.18 & 54.01 & 3.85 & 147.376 & 69.94018 \\
\hline 2. & F. hookeri Miq. & 0.24 & 65.58 & 2.89 & 118.0654 & 70.48909 \\
\hline 3. & M. philippensis (Lam.) Mull. Arg. & 0.33 & 73.49 & 2.1 & 106.189 & 60.71628 \\
\hline 4. & A. lakoocha Wall. ex Roxb. & 0.29 & 70.53 & 2.39 & 90.26995 & 54.23127 \\
\hline 5. & D. pentagyna Roxb. & 0.25 & 70.6 & 2.77 & 143.9757 & 62.31835 \\
\hline
\end{tabular}

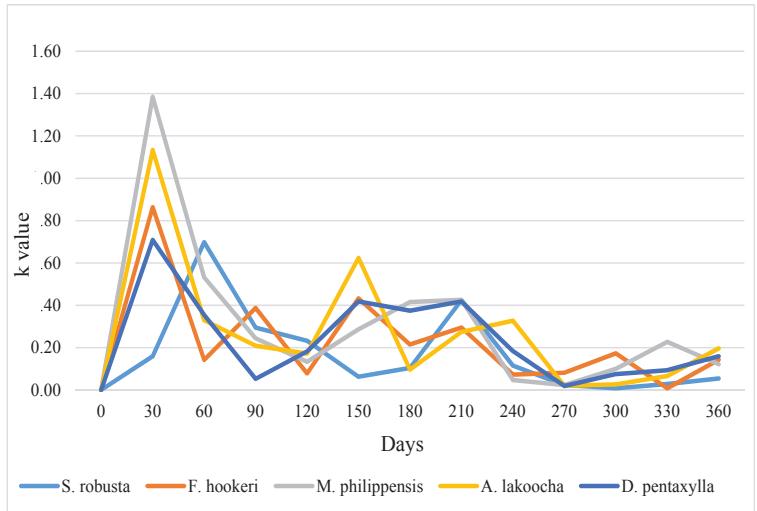

Figure 2: Leaf-liter decomposition rateconstant with respect to time

The decomposition rate-constant showed a significant positive correlation with the aerial temperature $(\mathrm{p}=000 ; \mathrm{r}=0.54)$ and rainfall $(\mathrm{p}$ $=0.000 ; \mathrm{r}=0.51)$. Hasanuzzaman and Hossain (2014) reported the concentration of the nutrients to have decreased gradually at the end of the experiment in a dry season whereas there was decrease in the initial stage but increase at the end of the experiment in the wet season. On the contrary, Salinas et al. (2011) concluded the temperature to be overwhelmingly the most important driver. However, Wieder et al. (2009) concluded the positive correlation between precipitation and leaf-litter decomposition along with the temperature. Hence, the physicochemical environment, litter quality and the composition of the decomposer community are the three leading features regulating litter decomposition (Dechaine et al., 2005).
Changes in nutrient concentration in decomposing litter

In general, there was a significant positive correlation (except $F$. hookeri) between the remaining weight and the $\mathrm{C}$ : $\mathrm{N}$ ratio (Table 3 ). Kim (2007) also concluded that the lower C : N ratio increased the rate of decomposition.

Table 3. Correlation between the remaining weight and the $O M, N, P \& K$

\begin{tabular}{|l|l|l|l|l|l|l|}
\hline Species & Value & OM & N & P & K & C:N \\
\hline S. robusta & $\mathrm{p}$ & 0.04 & 0.000 & 0.482 & 0.194 & 0.000 \\
& $\mathrm{r}$ & 0.58 & -0.945 & -0.214 & -0.385 & 0.885 \\
F. hookeri & $\mathrm{p}$ & 0.27 & 0.302 & 0.315 & 0.915 & 0.216 \\
& $\mathrm{r}$ & 0.33 & -0.311 & -0.303 & -0.033 & 0.368 \\
M. philippensis & $\mathrm{p}$ & 0.42 & 0.005 & 0.901 & 0.021 & 0.019 \\
& $\mathrm{r}$ & 0.25 & -0.728 & -0.039 & -0.632 & 0.637 \\
A. lakoocha & $\mathrm{p}$ & 0.49 & 0.003 & 0.831 & 1.000 & 0.002 \\
& $\mathrm{r}$ & 0.21 & -0.756 & -0.066 & 0.000 & 0.773 \\
D. pentagyna & $\mathrm{p}$ & 0.92 & 0.001 & 0.231 & 0.168 & 0.048 \\
& $\mathrm{r}$ & -0.03 & -0.809 & 0.357 & -0.407 & 0.556
\end{tabular}

\section{Organic matter concentration}

The percentage of the OM showed a positive correlation with the remaining weight in all the species except $D$. pentagyna which showed a slightly negative correlation (Figure 3a). However, there was no significant relationship $(\mathrm{p}>0.05)$ between the remaining weight and the OM except in the case of S. robusta. The value of the remaining $\mathrm{OM}$ at monthly intervals showed high fluctuation for F. hookeri followed by M. philippensis. 


\section{Nitrogen concentration}

The initial $\mathrm{N}$ concentration of $A$. lakoocha $(0.07 \%)$, was found to be the highest followed by $F$. hookeri and $M$. philippensis each having $0.062 \%$. There was a continuous increase in $\mathrm{N}$ concentration (Figure 3b) of residual litter throughout the decomposition cycle in all the species, thus showing significant $(\mathrm{p}<0.05$, except in the case of $F$. hookeri) inverse linear relationship. At the end of the study period, the $\mathrm{N}$ concentration was more than one and half times higher than the initial in the case of all the species except $F$. hookeri whose concentration was just slightly higher than that at the initial phase. Similar to the findings of this study, an increase in $\mathrm{N}$ concentration was observed by Bargali et al. (2015), Arslan et al. (2010) and Bargali et al. (2006). This might have resulted from microbes taking up inorganic $\mathrm{N}$, i.e. fungal immobilization as microbes require nutrients like $\mathrm{N}$ and $\mathrm{P}$ for their growth, and they have to take sufficient $\mathrm{N}$ to use $\mathrm{C}$ containing materials (Bargali et al., 1993). Though there was an increasing pattern of nitrogen concentration during the study period, $F$. hookeri might provide mineralized $\mathrm{N}$ earlier than other species as this species showed less net change from the initial $\mathrm{N}$ content.

\section{Phosphorus concentration}

The initial $\mathrm{P}$ was found to be highest $(0.145 \%)$ in $D$. pentagyna followed by $F$. hookeri $(0.131 \%)$. Similar to the result of $\mathrm{N}$, the correlation between the remaining weight and the $\mathrm{P}$ was slightly negative except in the case of $D$. pentagyna which showed a positive relationship with the remaining weight (Figure 3c). However, the relation was not significant for any of the species $(p>0.05)$. This study showed that the net release of P was highest for $S$. robusta followed by D. pentagyna.

\section{Potassium concentration}

The remaining $\mathrm{P}$ concentration with time was more or less similar for all the species. The initial concentration was highest in $F$. hookeri (21.159\%) followed by A. lakoocha (5.295). The amount of $\mathrm{P}$ was found to have dramatically decreased during the first month for all the species and increased in the second month and again decreased in the third month (see Figure $3 d)$. The rate slightly fluctuated again at the last two months of the study period. The net release of $\mathrm{P}$ was highest in $F$. hookeri followed by A. lakoocha.

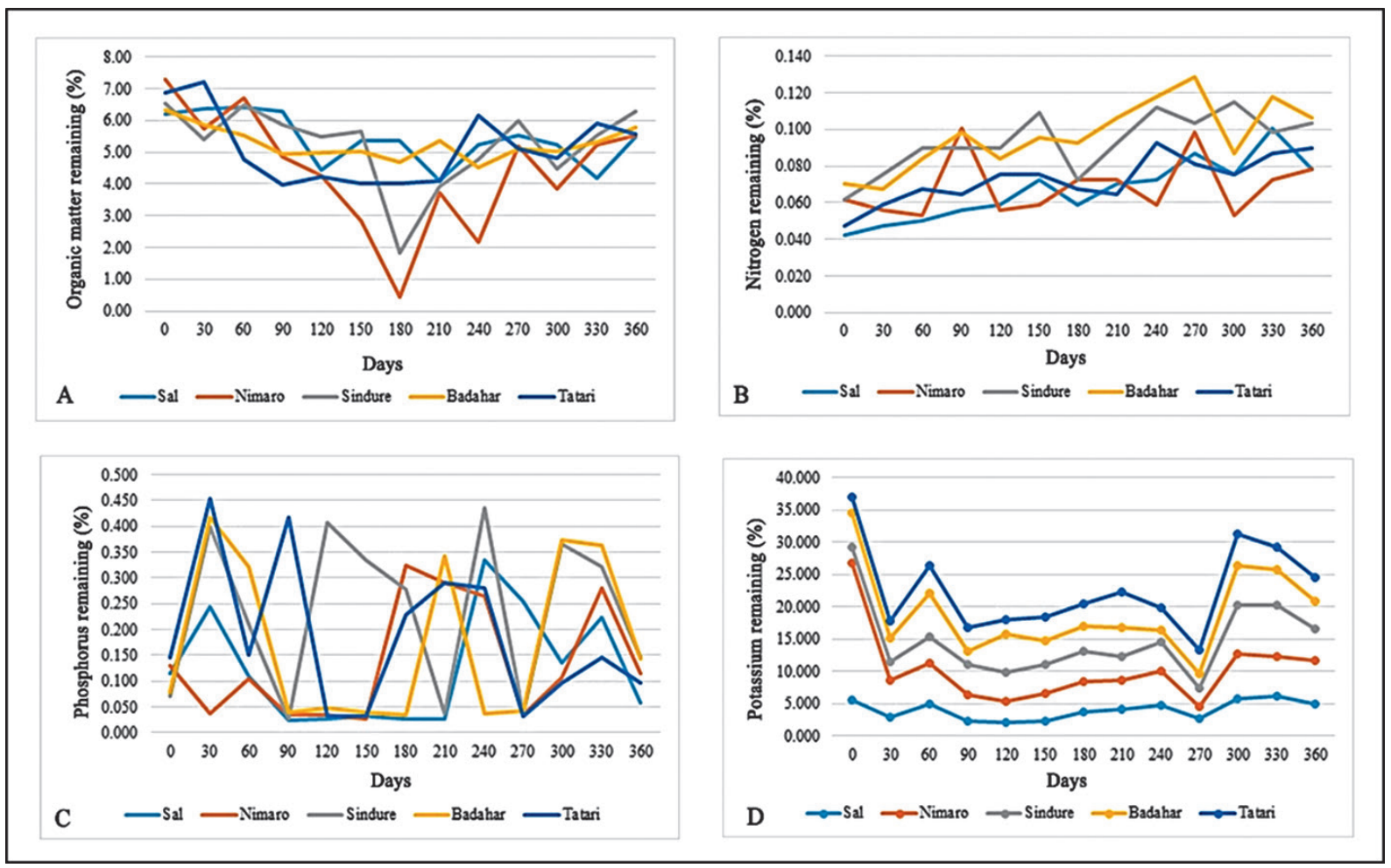

Figure 3a: Remaining OM (\%) with time; Figure 3b: Remaining N (\%) with time; Figure 3c: Remaining P (\%) with time; and Figure 3d: Remaining K (\%) with time 


\section{Conclusion}

Based on the present study, it can be concluded that the rate of decomposition of M. philippensis is highest followed by A. lakoocha whereas the rate of decomposition of $S$. robusta is lowest. Decomposition is a complex procedure heavily influenced by biotic and abiotic factors. Both decomposition rate-constant and weight loss were highest for M. philippensis $(\%$ weight loss $=73.49$; $\mathrm{k}=0.33)$ and lowest for $S$. robusta $(\%$ weight loss $=$ $54.01 ; \mathrm{k}=0.18)$. In general, the weight remaining was strongly negatively correlated with $\mathrm{N}$ and $\mathrm{P}$ concentrations but slightly negatively correlated with $\mathrm{K}$ concentration. However, there was a strong positive correlation between the remaining $\mathrm{OM}$ and $\mathrm{C}: \mathrm{N}$ ratio for all the species. The study showed that there was no net release of $\mathrm{N}$ during the one-year study period, thus indicating none of the species to be the immediate source for $\mathrm{N}$ to the soil. However, the net $\mathrm{P}$ release was highest for $S$. robusta followed by D. pentagyna while the net $\mathrm{K}$ release was highest in $F$. hookeri followed by $A$. lakoocha.

\section{Acknowledgments}

The authors are thankful to Mr. Rajesh Tamang, Mr. Amod Mallik, Ms. Samrajya Subedi, Ms. Roshani Bhatta, Ms. Shrijana Acharya and Mr. Bhola Chaudhary for assisting us during sample collection and monthly treatment of the collected samples. The Faculty of Forestry (Agriculture and Forestry University), the Soil Laboratory, Hetauda, the Plant Research Center, Hetauda and the Department of Hydrology and Meteorology are highly acknowledged for various supports during this study. The authors are grateful to the Directorate of Research and Extension (Agriculture and Forestry University) for providing financial support to carry out this research.

\section{References}

Allan, D. J., and Castillo, M. M. (2007). Stream ecology : structure and function of running waters, $2^{\text {nd }}$ edition. Springer, New York.

Arslan, H., Gurcan, G. and Kirmizi, S. (2010). Nitrogen mineralization in the soil of indigenous oak and pine plantation forests in a Mediterranean environment. European Journal of Soil Biology 46 : 11-17.
Austin, A. T. and Vitousek, P. M. (2000). Precipitation, decomposition and litter decomposability of Metrosideros polymorpha in native forests on Hawai. Journal of Ecology 88 : 129-138.

Bargali, S. S., Singh, S. P. and Singh, R. P. (1993). Pattern of weight loss and nutrients release from decomposing leaf-litter in age series of eucalypt plantations. Soil Biology and Biochemistry 25 : 1731-1738.

Bargali, S. S., Pandey, C. B. and Sharma, D. K. (2006). Weight loss and nitrogen release pattern in leaf and wood litter of Gliricidia sepium (Jacq. ) Walp. Bulletin of the National Institute of Ecology 17 : 25-29.

Bargali, S. S., Shukla, K., Singh, L., Ghosh, L. and Lakhera, M. L. (2015). Leaf-litter decomposition and nutrient dynamics in four tree species of dry deciduous forest. Tropical Ecology 56 (2) : 191-200.

Berg, B. and McClaugherty, C. (2014). Plant litter : decomposition, humus formation, carbon sequestration. Springer-Verlag, Berlin, Germany.

Brady, N. and Weil, R. (2010). The nature and properties of soils. Pearson, Upper Saddle River.

Chapman, S. K. and Koch, G. W. (2007). What type of diversity yields synergy during mixed litter decomposition in a natural forest ecosystem? Plant Soil 299 : 153162.

Dechaine, J., Ruan, H., Sanchez deLeon, Y. and Zou, X. (2005). Correlation between earthworms and plant-litter decomposition in a tropical wet forest of Puerto Rico. Pedobiologia 49 (6) : 601-607.

Gautam, T. P. and Mandal, T. N. (2016). Effect of disturbance on litter dynamics in moist tropical forest of eastern Nepal. Our Nature $14(1): 1-12$.

Gilbert, O. and Bocock, K. L. (1960). Changes in the leaf-litter when placed on the surface of soils with contrasting humus types. II. Changes in the nitrogen content of oak 
and ash litter. Journal of Soil Science 11 : 10-19.

Guendehou, G. H. S., Liski, J., Tuomi, M., Moudachirou, M., Sinsin, B. and Makipaa, R. (2014). Decomposition and changes in chemical composition of leaf-litter of five dominant tree species in a west African tropical forest. Tropical Ecology 55 : 207-220.

Hasanuzzaman, Md. and Hossain, M. (2014). Leaf-litter decomposition and nutrient dynamics associated with common horticultural cropland agroforestry tree species of Bangladesh. International Journal of Forestry Research 2014 (1) : pages?

Hauer, R. F. and Lamberti, L. A. (2006). Methods in Stream Ecology. $2^{\text {nd }}$ edition. Academic, Waltham.

Isaac, S. R. and Nair, M. A. (2005). Biodegradation of leaf-litters in the warm humid tropics of Kerala, India. Soil Biology and Biochemistry 37 : 1656-1664.

Jackson, M. L. (1967). Soil chemical analysis. Prentice Hall, New Jersey. p. 498.

Kim, J. S. (2007). Litter decomposition and nitrogen release in three Quercus species at temperate broad-leaved forest. Forest Science and Technology 3 (2) : 123-131.

Olsen, J. S. (1963). Energy storage and the balance of producers and decomposers in ecological systems. Ecology 44 : 322-331.

Ross, D. J., Tate, K. R., Newton, P. C. D. and Clark, H. (2002). De- composability of C3 and C4 Grass-litter sampled under different concentrations of atmospheric carbon dioxide at a natural $\mathrm{CO} 2$ spring. Plant and Soil 240 (2) : 275-286. doi : 10. 1023/A : 1015779431271 .
Saha, S., Rajwar, G. S., Kumar, M. and Upadhaya, K. (2016). Litter production, decomposition and nutrient release of woody tree species in Dhanaulti region of temperate forest in Garhwal Himalaya. Eurasian Journal of Forest Science 4 (1) : 17-30.

Salinas, N., Malhi, Y., Silman, M., Cuesta, R. R., Huaman, J., Salinas, D., Huaman, V., Gibaja, A., Mamani, M. and Farfan, F. (2011). The sensitivity of tropical leaf-litter decomposition to temperature results from a large-scale leaf translocation experiment along an elevation gradient in Peruvian forest. New Phytologist 189 : 967-977.

Silveira, M. L., Reddy, K. R., and Comerford, N. B. (2011). Litter decomposition and soluble carbon, nitrogen and phosphorus release in a forest ecosystem. Open Journal of soil Science 1 : 86-96.

Singh, L., Singh, A., Bargali, S. S. and Upadhyay, V. P. (2007). Leaf-litter decomposition and nutrient release pattern in multipurpose tree species of central India. Journal of Basic and Applied Biology 1 : 14-21.

Usman, S., Singh, S. P., Rawat, Y. S. and Bargali, S. S. (2000). Fine root decomposition and nitrogen mineralization pattern in Quercus leucotrichophora and Pinus roxburghii forest in central Himalaya. Forest Ecology and Management 131 : 191-199.

Wieder, W. R., Cleveland, C. C. and Townsend, A. R. (2009). Control over leaf-litter decomposition in wet tropical forests. Ecology 90 (12) : 3333-3341. 